\title{
Prevalence of diphtheria and tetanus antibodies and circulation of Corynebacterium diphtheriae in São Paulo, Brazil
}

K.G. Divino-Goes ${ }^{1}$, M.I. de Moraes-Pinto ${ }^{1}$, M.I.S. Dinelli ${ }^{1}$,

S.T. Casagrande ${ }^{2 \dagger}$, T.C.S. Bonetti ${ }^{1}$, P.R. Andrade ${ }^{3}$ and L.Y. Weckx ${ }^{1}$

\author{
'Disciplina de Infectologia Pediátrica, Departamento de Pediatria, \\ Escola Paulista de Medicina, Universidade Federal de São Paulo, \\ São Paulo, SP, Brasil \\ ${ }^{2}$ Instituto Adolfo Lutz, São Paulo, SP, Brasil \\ ${ }^{3}$ Centro Assistencial Cruz de Malta, São Paulo, SP, Brasil
}

\section{Correspondence \\ M.I. de Moraes-Pinto \\ Disciplina de Infectologia \\ Pediátrica \\ Departamento de Pediatria \\ EPM, UNIFESP \\ Rua Pedro de Toledo, 781, 90 andar \\ 04039-032 São Paulo, SP \\ Brasil \\ Fax: +55-11-5575.6928 \\ E-mail: m.isabelmp@uol.com.br \\ †In memoriam.}

Research supported by FAPESP (No. 01/07918-6) and CAPES.

Received February 5, 2007 Accepted July 4, 2007

\begin{abstract}
The introduction of routine vaccination against tetanus and diphtheria in Brazil has decreased the incidence and changed the epidemiology of both diseases. We then investigated the prevalence of Corynebacterium diphtheriae carrier status and diphtheria and tetanus immunity in São Paulo, Brazil. From November 2001 to March 2003, 374 individuals were tested for the presence of $C$. diphtheriae in the nasooropharynx and of serum diphtheria and tetanus antibodies. Participants were all healthy individuals without acute or chronic pathologies and they were stratified by age as follows: $0-12$ months and 1-4, $5-9,10-14,15-24,25-39,40-59$, and $\geq 60$ years. Antibodies were assessed using a double-antigen ELISA. $C$. diphtheriae species were identified by biochemical analysis and toxigenicity was assessed by the Elek test. For diphtheria, full protection (antibodies $\geq 0.1 \mathrm{IU} / \mathrm{mL}$ ) was present in $84 \%$ of the individuals, $15 \%$ had basic protection (antibodies $\geq 0.01$ and $<0.1 \mathrm{IU} / \mathrm{mL}$ ) and $1 \%$ were susceptible (antibodies $<0.01 \mathrm{IU} / \mathrm{mL}$ ). Full tetanus protection (antibodies $\geq 0.1 \mathrm{IU} / \mathrm{mL}$ ) was present in $79 \%$ of the participants, $18 \%$ had basic protection (antibodies $\geq 0.01$ and $<0.1 \mathrm{IU} / \mathrm{mL}$ ) and $3 \%$ were susceptible (antibodies $<0.01 \mathrm{IU} / \mathrm{mL}$ ). The geometric mean of diphtheria and tetanus antibodies reached the highest values at 5-9 years and decreased until the 40-59-year age range, increasing again in individuals over 60 years. Three participants $(0.8 \%)$ were carriers of $C$. diphtheriae, all non-toxigenic strains. The present results demonstrate the clear need of periodic booster for tetanus and diphtheria vaccine in adolescents and adults after primary immunization in childhood.
\end{abstract}

Prior to the availability of a vaccination, immunity against diphtheria occurred through infection in childhood and was maintained in adulthood by frequent natural boosters
Key words - Diphtheria

- Tetanus

- Corynebacterium diphtheriae

- Vaccine

- Immunization

- Antibody (1) 
that immunity against the disease is now provided by primary vaccination during the first months of life. Immunization led to a marked decrease in the incidence of the disease and to a subsequent decrease in the reservoir of toxigenic Corynebacterium diphtheriae organisms (1). In this setting, immunity against diphtheria can only be maintained in adults if routine booster doses of diphtheria toxoid are administered.

Moreover, vaccination coverage must be high and uniform in all age groups, so that pools of susceptible individuals do not form. When an imported source of infection occurs, the presence of susceptible groups can favor the circulation of $C$. diphtheriae toxigenic strains. Eventually, that can cause a diphtheria epidemic as the one that occurred recently in the newly independent states of the former Soviet Union (2).

In view of this, routine epidemiological surveys help check the maintenance of the protective antibody levels against the disease. Interestingly, since tetanus and diphtheria toxoids are administered together, immunity against both diseases tends to develop concomitantly, although not at the same intensity.

In the present study, we have assessed the prevalence of diphtheria and tetanus antibodies and the circulation of $C$. diphtheriae in São Paulo, Brazil. The investigation was conducted from September 2001 to March 2003 at the Federal University of São Paulo and at the Adolfo Lutz Institute, São Paulo, Brazil. The Ethics Committee of both institutions approved the protocol and written informed consent was obtained from each subject before enrollment.

The participants were 374 individuals (146 males and 228 females) stratified by age: 0 to 12 months $(\mathrm{N}=20), 1$ to $4(\mathrm{~N}=49)$, 5 to $9(\mathrm{~N}=54), 10$ to $14(\mathrm{~N}=35), 15$ to $24(\mathrm{~N}$ $=48), 25$ to $39(\mathrm{~N}=65), 40$ to $59(\mathrm{~N}=50)$, and 60 years or older $(\mathrm{N}=53)$.

Individuals were recruited using a convenience sampling method at Cruz de Malta
Center $(60 \%)$ and at the Federal University of São Paulo (40\%), in the city of São Paulo, SP, Brazil. They were all healthy individuals. Exclusion criteria were presence of acute infectious diseases, cancer, congenital or acquired immune deficiency, use of antibiotics in the previous 15 days, hospitalization for more than $24 \mathrm{~h}$ in the previous 30 days, and living in an institution.

A form was completed with age and history of previous immunization. Five milliliters of venous blood was collected from all participants on entry into the study. Serum samples were separated and stored at $-80^{\circ} \mathrm{C}$ until testing.

Calcium alginate swabs (DME, Araçatuba, SP, Brazil) were used to collect samples, one from the nasopharynx and the other from the oropharynx. The samples were immediately placed on a dish with cystine and tellurite blood agar and incubated for $48 \mathrm{~h}$ at $37^{\circ} \mathrm{C}$. When skin wounds were present, swab samples were also collected.

Serologic assays were performed at the Research Laboratory of the Pediatric Infectious Diseases Division, Federal University of São Paulo, Brazil. Diphtheria and tetanus antibodies were measured by an in-house double-antigen ELISA as described by Kristiansen et al. (3), which shows a good correlation with established toxin neutralizing assays and is functionally specific for IgG antibodies. For diphtheria antibodies, $50 \mathrm{ng} / \mathrm{mL}$ diphtheria toxoid (Butantan Institute, São Paulo, SP, Brazil) diluted in $0.1 \mathrm{M}$ carbonate-bicarbonate buffer, $\mathrm{pH}$ 9.6, was used to coat 96-well microtiter plates (Thermolab Systems, Vantaa, Finland) overnight at $4^{\circ} \mathrm{C}$. Two-fold serial dilutions of serum samples and of diphtheria reference serum (in-house standard calibrated against "Diphtheria antitoxin human serum 91/534" NIBSC reagent) in dilution buffer $(0.01 \mathrm{M}$ PBS, $\mathrm{pH} 7.2$, and $1 \%$ Triton $\mathrm{X}-100$ ) with $1 \%$ bovine serum albumin were added to the plate and incubated for $1 \mathrm{~h}$ at $37^{\circ} \mathrm{C}$. For the next step, biotin-labeled diphtheria toxoid in 
dilution buffer was added to the plate and incubated for an additional $1 \mathrm{~h}$ at $37^{\circ} \mathrm{C}$. Streptavidin-alkaline phosphatase conjugate (Zymed, San Francisco, CA, USA) in dilution buffer was incubated for $1 \mathrm{~h}$ at $37^{\circ} \mathrm{C}$. $p$ Nitrophenyl-phosphate (Sigma, St. Louis, MO, USA) in $1 \mathrm{M}$ diethanolamine and $5 \mathrm{mM}$ magnesium chloride buffer, $\mathrm{pH} 9.8$, was used as substrate and absorbance was read at 450 $\mathrm{nm}$ in an immunoreader ELX-800 (Bio-Tek Instruments, Winooski, VT, USA). Between steps, the plate was washed five times using a dilution buffer.

For tetanus antibodies, the same method was applied with some modifications: $80 \mathrm{ng} /$ $\mathrm{mL}$ tetanus toxoid (Butantan Institute), tetanus reference serum (in-house standard calibrated against "Tetanus antitoxin human immunoglobulin NIBSC reagent 1976 (76/ 589)") and biotin-labeled tetanus toxoid were used as substitutes for the corresponding diphtheria reagents. Diphtheria and tetanus antibodies were reported in international units per milliliter (IU/mL) using the curve comparison method to transform absorbance to concentration units.

Intra-assay coefficients varied from 1.8 to $2.7 \%$ for diphtheria ELISA and from 0.9 to $3.2 \%$ for tetanus ELISA. Inter-assay variation varied from 4.9 to $15.2 \%$ for diphtheria ELISA and from 8.9 to $47.5 \%$ for tetanus ELISA. Higher coefficients were only found among samples of very low antibody levels (e.g., $0.011 \mathrm{IU} / \mathrm{mL}$ ), so that they $\mathrm{did}$ not interfere with results.

Patients were classified according to internationally accepted criteria of protective antibody levels $(4,5)$. Individuals with diphtheria and tetanus antibody concentrations lower than $0.01 \mathrm{IU} / \mathrm{mL}$ were considered to be without protection and individuals with levels equal to or greater than $0.1 \mathrm{IU} / \mathrm{mL}$ were considered to be fully protected. Those with antibodies equal to or greater than 0.01 $\mathrm{IU} / \mathrm{mL}$ and less than $0.1 \mathrm{IU} / \mathrm{mL}$ were classified as having basic immunity, which protects most individuals against the disease, but is usually considered to be a short-term protection.

The microbiological characterization of the bacteria was done according to the Centers for Disease Control and Prevention Manual (6) with some modifications introduced at the Adolfo Lutz Institute in their routine identification of $C$. diphtheriae. After $48 \mathrm{~h}$ of incubation at $37^{\circ} \mathrm{C}$, in the event of growth of characteristic colonies, which could vary from a grayish color to a darker one, four colonies were transferred to four different Pai medium slants and incubated for $24 \mathrm{~h}$ at $37^{\circ} \mathrm{C}$. After this procedure, if the colony remained the same color as the medium and had a butter consistence, a scrape of the Pai medium was obtained and transferred to a Pisu medium to detect production of $\mathrm{H}_{2} \mathrm{~S}$. Simultaneously, the Albert-Laybourn color test was performed to check for the presence of metachromatic granules; if present, the $C$. diphtheriae would appear as green or blue color, sometimes chestnut brown. The diphtheria bacilli were identified after biochemical tests for the detection of sugar fermentation, urea hydrolysis, nitrate reduction, and the presence of catalase and oxidase. The first reading was performed at 24 $h$, when sugar fermentation was observed and the nitrate enzymatic test was carried out. The biochemical tests were incubated for 5 days because of the possibility of later fermentation of sugars.

In the present study, the biotypes of $C$. diphtheriae were classified as gravis, mitis and intermedius according to hemolysis in blood agar and glucogen fermentation. The Elek test was performed to detect the toxigenicity of $C$. diphtheriae. Results were read within 15 days and were considered positive for a toxigenic strain if a white precipitation perpendicular to the strain growth was observed. Control strains for $C$. diphtheriae were NCTC 10356, PW8 and NCTC 12078.

Antibody levels were submitted to logarithmic transformation before statistical analysis due to their non-normal distribution. 
Mean diphtheria antibody levels in different age groups and mean diphtheria and tetanus antibody levels in each age group were compared by ANOVA. Games-Howell correction was employed to compare antibody levels among age groups due to the variance between them. ANOVA and Games-Howell correction were performed using the SPSS 10.01 software (1999) and geometric means and confidence interval were calculated using the STATA 7.0 software.

Overall, only $1 \%(5 / 374)$ of the population studied was considered to be susceptible to diphtheria; $15 \%$ (57/374) had basic immunity and $84 \%(312 / 374)$ were fully protected. For tetanus, 3\% (13/374) were susceptible, 18\% (68/374) had basic immunity and 79\% (293/374) were fully protected (Table 1).

Geometric mean tetanus antibody levels were higher than diphtheria levels up to the age range of 40 to 59 years, when they were similar. Geometric mean diphtheria antibody levels were higher than tetanus antibody levels only for the age group of individuals aged 60 years or over (Figure 1). Statistical differences between geometric mean diphtheria and tetanus antibody levels were observed within the age group of 5 to 9 years of age, in which children had higher tetanus antibodies $(\mathrm{P}<0.001)$ and in the age group of 60 years or over, in which individuals had higher geometric mean diphtheria antibody levels ( $\mathrm{P}=0.007$; Figure 1$)$.

When mean diphtheria antibody levels of different age groups were compared, individuals 60 years or over had higher levels $(0.94 \mathrm{IU} / \mathrm{mL})$ than those aged 0 to 12 months (0.09 IU/mL; Games-Howell, P > 0.001), 1 to 4 years $(0.35 \mathrm{IU} / \mathrm{mL}$; Games-Howell, $\mathrm{P}=$ $0.04), 25$ to 39 years $(0.35 \mathrm{IU} / \mathrm{mL}$; GamesHowell, $\mathrm{P}=0.012)$, and 40 to 59 years $(0.21$ $\mathrm{IU} / \mathrm{mL}$; Games-Howell, $\mathrm{P}>0.001)$. The 5to 9-year-old group (0.64 IU/mL) also had significantly higher diphtheria antibody levels than the 40- to 59-year-old group (0.21 $\mathrm{IU} / \mathrm{mL}$; Games-Howell, $\mathrm{P}=0.004$; Figure 1).

The lowest mean diphtheria antibody levels were observed in children under 12 months of age $(0.09 \mathrm{IU} / \mathrm{mL})$, with a statistically significant difference when compared to the age groups of 5 to 9 years $(0.64 \mathrm{IU} /$ $\mathrm{mL}$; Games-Howell, $\mathrm{P}<0.001), 10$ to 14 years $(0.45 \mathrm{IU} / \mathrm{mL}$; Games-Howell, $\mathrm{P}=$ $0.005), 15$ to 24 years $(0.47 \mathrm{IU} / \mathrm{mL}$; GamesHowell, $\mathrm{P}=0.004)$, and 25 to 39 years $(0.35$ $\mathrm{IU} / \mathrm{mL}$; Games-Howell, $\mathrm{P}=0.029$; Figure 1).

Table 1. Tetanus and diphtheria antibody levels according to subject age.

\begin{tabular}{|c|c|c|c|c|c|c|c|}
\hline \multirow[t]{3}{*}{ Age groups } & \multirow[t]{3}{*}{ Total number } & \multicolumn{6}{|c|}{ Categories of immunity } \\
\hline & & \multicolumn{3}{|c|}{ Diphtheria } & \multicolumn{3}{|c|}{ Tetanus } \\
\hline & & $\begin{array}{l}\text { Full protection } \\
(\geq 0.1 \mathrm{IU} / \mathrm{mL})\end{array}$ & $\begin{array}{c}\text { Basic protection } \\
(\geq 0.01 \text { and }<0.1 \mathrm{IU} / \mathrm{mL})\end{array}$ & $\begin{array}{l}\text { No protection } \\
(<0.01 \mathrm{IU} / \mathrm{mL})\end{array}$ & $\begin{array}{l}\text { Full protection } \\
(\geq 0.1 \mathrm{IU} / \mathrm{mL})\end{array}$ & $\begin{array}{c}\text { Basic protection } \\
(\geq 0.01 \text { and }<0.1 \mathrm{IU} / \mathrm{mL})\end{array}$ & $\begin{array}{l}\text { No protection } \\
(<0.01 \mathrm{IU} / \mathrm{mL})\end{array}$ \\
\hline 1-12 months & 20 & $11(55 \%)$ & 7 (35\%) & $2(10 \%)$ & $13(65 \%)$ & $4(20 \%)$ & $3(15 \%)$ \\
\hline $1-4$ years & 49 & $40(82 \%)$ & $7(14 \%)$ & $2(4 \%)$ & $45(92 \%)$ & $4(8 \%)$ & $0(0 \%)$ \\
\hline $5-9$ years & 54 & $52(96 \%)$ & $2(4 \%)$ & $0(0 \%)$ & $51(94 \%)$ & $3(6 \%)$ & $0(0 \%)$ \\
\hline $10-14$ years & 35 & 33 (94\%) & $2(6 \%)$ & $0(0 \%)$ & 31 (89\%) & $4(11 \%)$ & $0(0 \%)$ \\
\hline $15-24$ years & 48 & $44(92 \%)$ & $4(8 \%)$ & $0(0 \%)$ & $38(79 \%)$ & $9(19 \%)$ & $1(2 \%)$ \\
\hline 25-39 years & 65 & $52(80 \%)$ & $12(18 \%)$ & $1(2 \%)$ & $49(75 \%)$ & $14(22 \%)$ & $2(3 \%)$ \\
\hline $40-59$ years & 50 & $32(64 \%)$ & $18(36 \%)$ & $0(0 \%)$ & $30(60 \%)$ & $17(34 \%)$ & $3(6 \%)$ \\
\hline$\geq 60$ years & 53 & 48 (91\%) & $5(9 \%)$ & $0(0 \%)$ & $36(68 \%)$ & $13(24 \%)$ & $4(8 \%)$ \\
\hline Total number & 374 & 312 (84\%) & 57 (15\%) & $5(1 \%)$ & 293 (79\%) & $68(18 \%)$ & $13(3 \%)$ \\
\hline
\end{tabular}

Data are reported as number with percent in parentheses. 
For tetanus, the 5- to 9-year-old group had higher mean antibody levels (1.28 IU/ $\mathrm{mL}$ ) when compared to the age groups of 0 to 12 months $(0.19 \mathrm{IU} / \mathrm{mL}$; Games-Howell, $\mathrm{P}=0.014), 25$ to 39 years $(0.39 \mathrm{IU} / \mathrm{mL}$; Games-Howell, $\mathrm{P}=0.002$ ), 40 to 59 years (0.19 IU/mL; Games-Howell, $\mathrm{P}<0.001)$, and 60 years or older $(0.27 \mathrm{IU} / \mathrm{mL}$; GamesHowell, $\mathrm{P}<0.001$; Figure 1). The age group of 40 to 59 years had significantly lower levels than the age groups of 1 to 4 years (0.74 IU/mL; Games-Howell, P = 0.001), 10 to 14 years $(0.62 \mathrm{IU} / \mathrm{mL}$; Games-Howell, $\mathrm{P}$ $=0.029)$ and 15 to 24 years $(0.69 \mathrm{IU} / \mathrm{mL}$; Games-Howell, $\mathrm{P}=0.022$ ).

Immunization rates by age stratum followed a similar trend: $92 \%$ for 0 - to 6month-old infants, $100 \%$ for 7- to 12-monthold infants, $88 \%$ for 1- to 4-year-old children, $90 \%$ for individuals aged 5 to 9 years, $89 \%$ for those aged 10 to 14 years, $59 \%$ for those aged 15 to 24 years, $59 \%$ for those aged 25 to 39 years, $18 \%$ for those aged 40 to 59 years, and $78 \%$ for those above 60 years of age.

Three of 374 individuals proved to be carriers of $C$. diphtheriae, one with the mitis biotype and two with the gravis biotype, all of them atoxigenic strains. They were two children, aged 4 and 5 years, and a 20-yearold female. Both children had been fully immunized, as confirmed by their vaccination records. The woman reported not having been previously vaccinated against tetanus and diphtheria. All of them had protective antibody levels against tetanus and diphtheria. A nasopharynx and oropharynx swab from all family members of the 3 carriers was collected, but no $C$. diphtheriae strains were found.

In Brazil, the high coverage of diphtheria-tetanus-pertussis (DTP) vaccination has led to an important reduction in the number of diphtheria cases and deaths over the last

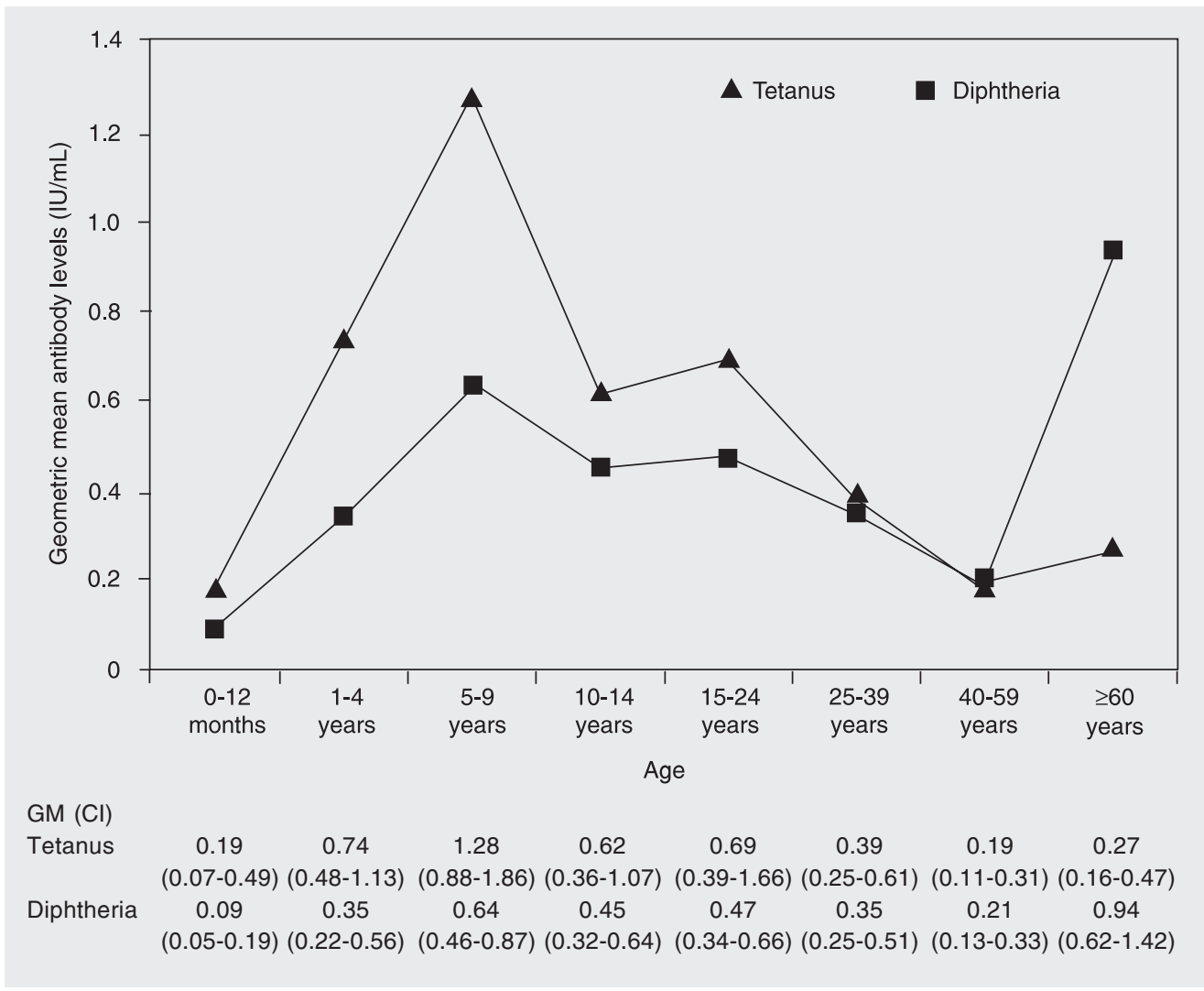

Figure 1. Geometric means (GM) of diphtheria and tetanus antibody levels as a function of age group. $\mathrm{Cl}=$ confidence interval at $95 \%$. 
two decades (7). The present immunization schedule in Brazil includes 5 DTP doses at 2, $4,6,15$ months, and 4-6 years of age, followed by tetanus-diphtheria (Td) boosters every 10 years.

In the present study, we found that only $1 \%$ of the population was susceptible to diphtheria and $3 \%$ to tetanus. Almost all age groups had fully protective antibodies (mean antibody levels $\geq 0.1 \mathrm{IU} / \mathrm{mL}$ ). The exception was the 0 - to 12-month-old group, with mean antibody titers considered to be basic protective $(0.09 \mathrm{IU} / \mathrm{mL})$, probably because some children still had not received the 3 DTP doses when their blood was collected. Eight of the 20 infants in that age range were 7 months of age or older, and only 1 child did not have protective antibody levels against diphtheria, but was immune to tetanus. All of them had received 3 DTP vaccine doses.

Both mean diphtheria and tetanus antibodies increased with age and reached a peak in the 5- to 9-year-old group, when children should have had 5 DTP doses. That was followed by a decay in mean antibody titers for tetanus and diphtheria, with a subtle increase in the 15- to 24-year-old group, suggesting that many adolescents failed to receive the $\mathrm{Td}$ booster $(8,9)$. Indeed, while studying a group of Brazilian adolescents, we have recently shown that higher tetanus and diphtheria antibodies were found in those who had up-to-date vaccination records (8). In the United States (10) and Spain (11) the proportion of protective antibodies against tetanus and diphtheria also decreased from infancy to adolescence.

From the 15- to 24-year-old group on, mean antibody levels decreased progressively until the 40- to 59-year-old group and increased again in individuals 60 years or over. Researchers in the United States, Turkey, England, and Wales also showed that there was a decrease in the prevalence of tetanus and diphtheria protective antibodies from young adults to individuals 60 years or over $(10,12,13)$.
As previously reported by our group $(8,14)$ and by others $(12)$, tetanus antibodies elicited by vaccination are usually present in higher concentration than diphtheria antibodies. In the present study, tetanus antibody levels were higher than diphtheria antibodies in all age groups, the only exception being individuals over 60 years of age, who showed geometric mean antibody concentrations against diphtheria well above those for tetanus. Those subjects were born when immunity against the disease was acquired through infection with diphtheria bacilli, and vaccination against diphtheria and tetanus had not been routinely introduced. In 1999 a National Influenza, Pneumococcus, Tetanus, and Diphtheria Vaccination Campaign for the Elderly was launched in Brazil, and has been continuing every year $(7,15)$. It is probable that, for some elderly people, the $\mathrm{Td}$ vaccine acted as a booster for diphtheria even though it was part of primary immunization for tetanus (16).

The diphtheria and tetanus antibody levels shown by us are in agreement with the absence of toxigenic strains of $C$. diphtheriae in the oro-nasopharynx of the individuals we studied. Also, bacilli were not recovered from wounds. Our results are coherent with the decrease in diphtheria cases in São Paulo State to rates between 0.01 to 0.05 per 100,000 inhabitants over the last 15 years (17). Other countries with low incidence of diphtheria have also low or no circulation of diphtheria bacilli $(18,19)$.

Recent studies assessing diphtheria and tetanus antibody levels have been performed in Brazil, but most of them included specific population or age groups $(8,14,16)$. It can be argued that the present study population may not be representative of São Paulo city. However, since it involved all age strata, it permitted a comparison of immunity to tetanus and diphtheria according to age. Our results showed that children under 1 year and adults 40 to 59 years of age were the two groups at higher risk for both diseases. Interestingly, 
during the diphtheria epidemic in the Republic of Georgia in 1993 to 1996, children who did not have the complete primary vaccination series with diphtheria toxoid and adults between 40 and 49 years of age were those with the highest fatality rate among the 659 patients identified with diphtheria (20).

These findings highlight the need for maintenance of protective antibody levels through basic immunization in children. Efforts must also be undertaken to encourage boosters in adolescents and adults. In the case of the Brazilian population, that seems especially important for the 40- to 59-year age stratum.

\section{References}

1. Galazka A. The changing epidemiology of diphtheria in the vaccine era. J Infect Dis 2000; 181 (Suppl 1): S2-S9.

2. Dittmann S, Wharton M, Vitek C, Ciotti M, Galazka A, Guichard S, et al. Successful control of epidemic diphtheria in the states of the Former Union of Soviet Socialist Republics: lessons learned. $J$ Infect Dis 2000; 181 (Suppl 1): S10-S22.

3. Kristiansen M, Aggerbeck H, Heron I. Improved ELISA for determination of anti-diphtheria and/or anti-tetanus antitoxin antibodies in sera. APMIS 1997; 105: 843-853.

4. Galazka AM. The immunological basis for immunization series. Module 2: Diphtheria. Geneva: World Health Organization; 1993.

5. Galazka AM. The immunological basis for immunization series. Module 3: Tetanus. Geneva: World Health Organization; 1993.

6. Centers for Diseases Control and Prevention. Laboratory requirement for isolation, identification and toxigenicity testing of Corynebacterium diphtheriae. Atlanta: Diphtheria Research Program; 1998.

7. Brazilian Ministry of Health. National Immunization Program 30 years. http://portal.saude.gov.br/portal/arquivos/pdf/livro_30_anos_ pni.pdf. Accessed September 21, 2005.

8. Dinelli Ml, Fisberg M, de Moraes-Pinto Ml. Tetanus and diphtheria immunity in adolescents from São Paulo, Brazil. Braz J Med Biol Res 2007; 40: 259-263.

9. Heininger U, Loos K, Lorenz I, Rascher W. Compliance with recommended immunizations in adolescents. Eur J Pediatr 2006; 165: 671-676.

10. McQuillan GM, Kruszon-Moran D, Deforest A, Chu SY, Wharton M. Serologic immunity to diphtheria and tetanus in the United States. Ann Intern Med 2002; 136: 660-666.

11. Pachon I, Amela C, de Ory F. Age-specific seroprevalence of poliomyelitis, diphtheria and tetanus antibodies in Spain. Epidemiol Infect 2002; 129: 535-541.

12. Maple PA, Jones CS, Wall EC, Vyseb A, Edmunds WJ, Andrews NJ, et al. Immunity to diphtheria and tetanus in England and Wales.
Vaccine 2000; 19: 167-173.

13. Caglar K, Karakus R, Aybay C. Determination of tetanus antibodies by a double-antigen enzyme-linked immunosorbent assay in individuals of various age groups. Eur J Clin Microbiol Infect Dis 2005; 24: 523-528.

14. Bonetti TC, Succi RC, Weckx LY, Tavares-Lopes L, de MoraesPinto Ml. Tetanus and diphtheria antibodies and response to a booster dose in Brazilian HIV-1-infected women. Vaccine 2004; 22 : 3707-3712.

15. Epidemiological Surveillance Center. National vaccination campaign for the elderly - 1999. http://cve.saude.sp.gov.br/doc_tec/bolcve/ boletim54.pdf. Accessed March 29, 2006.

16. Weckx LY, Divino-Goes K, Lihama DM, Carraro E, Bellei N, Granato $\mathrm{CF}$, et al. Effect of a single tetanus-diphtheria vaccine dose on the immunity of elderly people in São Paulo, Brazil. Braz J Med Biol Res 2006; 39: 519-523.

17. Epidemiological Surveillance Center. Cases, incidence $(100.000$ inhabitants), deaths and lethality in São Paulo State, 1970-2005. http://cve.saude.gov.br/htm/resp/difte_ob7002.htm. Accessed March 29, 2006.

18. Bergamini M, Fabrizi P, Pagani S, Grilli A, Severini R, Contini C. Evidence of increased carriage of Corynebacterium spp. in healthy individuals with low antibody titres against diphtheria toxoid. Epidemiol Infect 2000; 125: 105-112.

19. Dewinter LM, Bernard KA, Romney MG. Human clinical isolates of Corynebacterium diphtheriae and Corynebacterium ulcerans collected in Canada from 1999 to 2003 but not fitting reporting criteria for cases of diphtheria. $J$ Clin Microbiol 2005; 43: 3447-3449.

20. Quick ML, Sutter RW, Kobaidze K, Malakmadze N, Strebel PM, Nakashidze R, et al. Epidemic diphtheria in the Republic of Georgia, 1993-1996: risk factors for fatal outcome among hospitalized patients. J Infect Dis 2000; 181 (Suppl 1): S130-S137. 